\title{
THE EFFECT OF USING PICTURE STRIP STORY ON STUDENTS' SPEAKING SKILL
}

\author{
Eva Christina Turnip ${ }^{1}$ \\ Universitas Prima Indonesia \\ Ades Pranata Purba ${ }^{2}$ \\ Universitas Prima Indonesia \\ Eva Natalia Sitompul ${ }^{3}$ \\ Universitas Prima Indonesia \\ evachristina30@gmail.com ${ }^{1}$
}

Submit, 09-12-2019 Accepted, 30-01-2020 Publish, 26-02-2020

\begin{abstract}
This research was conducted at SMP YayasanPangeranAntasari, which located in Jl. Veteran No. 1060/19 Helvetia, Medan, North Sumatera. The data were collected by using a speaking test using pieces of pictures in narrative texts as the media. The results show the picture strip story has a positive effect on students' speaking skills through improving the students' speaking scores. This subject of this research were the students at the second grade A. This research was conducted by researchers starting with giving the pre-test to know the students' speaking ability before conducted the post-test in the last meeting, researchers treat the students using the picture strip story. This study shows the significant effect of using PST has a positive effect on students' speaking skill through the improvement of students' speaking scores. It was proven by the means in Posttest was higher than in Pre-test $(73,55-48,00)$. The t.obs $>$ t.table $(P=0,05)$, df(19). It means that Ha was accepted. Through the scores between Pre-test and Post-test shows a significant difference after being taught using the PST. Therefore, PST is one of some media which can be used to improve the students' speaking skill.
\end{abstract}

Keyword: Picture Strip Story, Speaking Skill, Effect.

\section{INTRODUCTION}

The main purpose of learning English is how to be able to use it. Some skills which are, speaking, writing, reading, and listening skills, must be mastered as the way to be able to use English. Between four skills above speaking is one of the most difficult skills to learn stated by Toyib \& Syafi'i (2018). It caused by students are afraid and anxious whenever they are in an evaluation situation or afraid of performing in the class because they think people will value them 
negatively stated by Izumi (2017). Teachers should give enough time for students to improve their skill especially in speaking skill, help them overcome their timidness through friendly behaviors to make them feel comfortable when speaking, remind their learners not to worry about making mistakes, and give them true instructions and enough guidance stated by Mei \& Masoumeh (2017). Therefore, solving the problem needed some appropriate technique, method, and strategy, which can help the students in speak up.

Choosing appropriate activities for speaking skills will be a good strategy in decreasing speaker anxiety as a factor affecting speaking skills. However, choosing the appropriate also support the students in mastering English. Especially in this research will explain how the PST can be a media that support the students speaking mastery. Through pictures, students can express their ideas (Kosdian, 2016). Khairunnisa (2015) stated that there is a significant effect in sing Picture Strip Story technique toward the speaking ability of the second-grade students.There is a significant difference in speaking achievement after implementing a strip story technique stated by Rifa'at (2018). After analyzing the data Purba \& Marbun (2019), outline the use of picture Strips, Storysignificantly affects the students' speaking ability. Some data above also support that the use of PST improve the students' speaking skill.

PST is one of the effective media which help to improve the students'.,speaking skills through the scores of the students in speaking tests. Besides improving speaking skills, the media also built the confidence of the students to speak up. Prawerti (2015), as a teaching technique, Strip Story shows the real effectiveness of motivating them to speak. Students will make into some groups and giving some pictures with strip stories. After that, ask them to discuss what will be the next picture for the sequences of the story. Then students will present what they discuss in front of the class with their own words. This research also shows how Picture Strip Story can have a positive effect on increasing the students' speaking skills. One of the skills that students should master in curriculum 2013 is speaking skills. As one of the schools which using 2013 curriculum, researchers deals to conduct this research to find out is there any effect of using PST through the scores of students' speaking test in the effect of students speaking skill

\section{LITERATURE REVIEW.}

Speaking skills produced by the period of learning the listening skill that is developed by language skills in child life is the definition of speaking (Tarigan, 1990). According to Nunan, as cited in Damayanti (2017) stated to express the ideas or precise words fluently, which can describe oneself, speaking activity is a 
way to achieve it. Those factors which support the speaking itself consist of some elements; they are:

1. Pronunciation is a difficult component of some language components. The phonology includes being deals with the other component. To make up the elements of the component of grammar, phonology, and principles, how sounds vary the pattern in language.

2. Vocabulary is the appropriate diction that communicates one to the other. Without the appropriate diction, students will have difficulties in speak up and interesting in learning the language. So, Students have to find a way how to expand their vocabulary.

3. Grammar, How the conversation consists of correct sentence arranges. Heaton, 1988:5 stated students be able to manipulate inappropriate the structure and to distinguish appropriate grammatical ones. To correct the way to gain expertise in a language, whether in oral and written form, the utility grammar needs to learn.

4. Fluency is being able to keep the language corning, as the way to keep the ability in speaking accurately suited.

According to wright, a picture strip story is a story that has been separated into smaller segments from beginning to end-a Picture strip story cup up to into separate pictures. One picture is handed to each member of the group. Without seeing each other's pictures, the learner in the group must decide on the original sequence and reconstruct the story. From the explanation, it concludes that picture strip story is a picture which can be decided into a smaller part base on some segments on the story from the beginning until the end of the story. Effect. The effect is an impact caused by something or someone. According to A.S Hornby, the writer concludes that the effect can be said as the influence that is appeared by something towards something else.

\section{RESEARCH METHOD}

In this research, use A pre-experimental design. One group pre-test and post-test as the design approach. Quantitative research was used as the research method that focused on the effect of students' scores before and after being taught by using PSD. This research was conducted to know whether there is any effect on students' scores after being taught The Picture Strip Story. The subject of this research was 20 students in the second grade of SMP Yayasan Pangeran Antasari. The researchers used the speaking test as the instrument in this research. The use of group or pair activities researchers conducted-to gets the data, where the students put into some groups and given a task, then they work together. The researcher's purpose of finding out is there any effect of the students' scores before and after being taught by using the Picture Strip Story. 
A test using narrative text which researchers form into Picture Strip Story used to get the data. A pre-test conducted by researchers was to find out the mean scores of the students' speaking ability. By looking at the difference, the researchers could conclude there is any effect of using picture strip story on students' scores before and after being taught the Picture Strip Story.

Table 1 The Test Illustration of Group Pre-Test and Post-Test Design.

\begin{tabular}{ccc}
\hline Type & Treatment & Type \\
\hline A & $\checkmark$ & B \\
\hline
\end{tabular}

A: Pre-Test

B: Post-Test

: Teaching Speaking using Picture Strips Story

Table 2 Teaching Procedure.

\begin{tabular}{|l|}
\hline \multicolumn{1}{|c|}{ Teaching Procedure } \\
\hline A. Pre-Test. \\
1. .Researchers divide the students into some groups. \\
2. Researchers give them one story with the title" the legend of Lake \\
Toba" and let them discuss the original sequence of the story, and \\
after students did, they present the results of their discussion. \\
\hline B. Treatment. \\
1. Researchers divide the students into some groups. \\
2. Researchers show the picture which has cut up into separate pictures \\
with one sentence. \\
3. Researchers give pictures to every group member to discuss and \\
determine the sequence of the story. \\
4. Researchers control the students' activity. \\
5. The students present the results of their discussion. \\
6. The researchers and students discussed the problem that they face in \\
their discussion. \\
C. Post- Test. \\
1. Researchers divide the students into some groups. \\
2. Researchers give them separate pictures with one sentence on a \\
story with the title" the legend of Lake Toba." \\
3. Students discuss the original sequence of the story, and after \\
students did, they present the results of their discussion in front of \\
the class.
\end{tabular}


The technique of data analysis was quantitative data. The students' scores in speaking test used by researchers to conclude whether any effect of students' scores by using the PST on student speaking skills. The speaking tests used by researchers are some pieces of pictures and sentences in narrative text. The test was given by researchers to the subject using four narrative texts; they are, The legend of Lake Toba, Timun Mas, Cinderella, and the legend of sangkuriang. The test was done in 60 minutes by students in groups. The researchers make sure the validation test by the validity test using SPSS 22 .

\section{FINDINGS}

The research was conducted on $12^{\text {th }}$ November 2019, after given the pretest, researchers conducted the treatment, and on the last meeting on $19^{\text {th }}$ November 2019 researchers conducted the post-test. Scores criteria are used by researchers to describe the data. Both of the good or bad scores of the test. The Score's criteria could be seen through this table below.

Table 3 Score's Criteria

\begin{tabular}{lll}
\hline No & \multicolumn{1}{c}{ Mean score } & \multicolumn{1}{c}{ Criteria } \\
\hline 1 & $81-100$ & Excellent \\
\hline 2 & $71-80$ & Very Good \\
\hline 3 & $61-70$ & Good \\
\hline 4 & $41-60$ & Poor \\
\hline 5 & $0-40$ & Low \\
\hline
\end{tabular}

To get the data, this research conducted by researchers in five meetings. The Pre-test is the first meeting, then followed by treatment, and the last meeting conducted the post-test.

Table 4 The Result of Descriptive Statistics

\begin{tabular}{lrrrrr}
\hline & N & Minimum & Maximum & Mean & $\begin{array}{c}\text { Std. } \\
\text { Deviation }\end{array}$ \\
\hline Nilai Pre-test & 20 & 10 & 74 & 48,00 & 14,242 \\
Nilai post-test & 20 & 60 & 80 & 73,55 & 5,414 \\
Valid N (listwise) & 20 & & & & \\
\hline
\end{tabular}


The mean score result of the pre-test and post-test was had a differentiate. The significant different show in the pre-test was 48.00 , while the mean score of the post-test was improved to be 73,55 . It was considered very good. Therefore, to find out whether $\mathrm{Ha}$ or $\mathrm{H} 0$ could be accepted or not, researchers conduct the TTest through SPSS 22 and using the paired-samples T-Test formula for the hypothesis test.

Table 5 Paired Sample Test

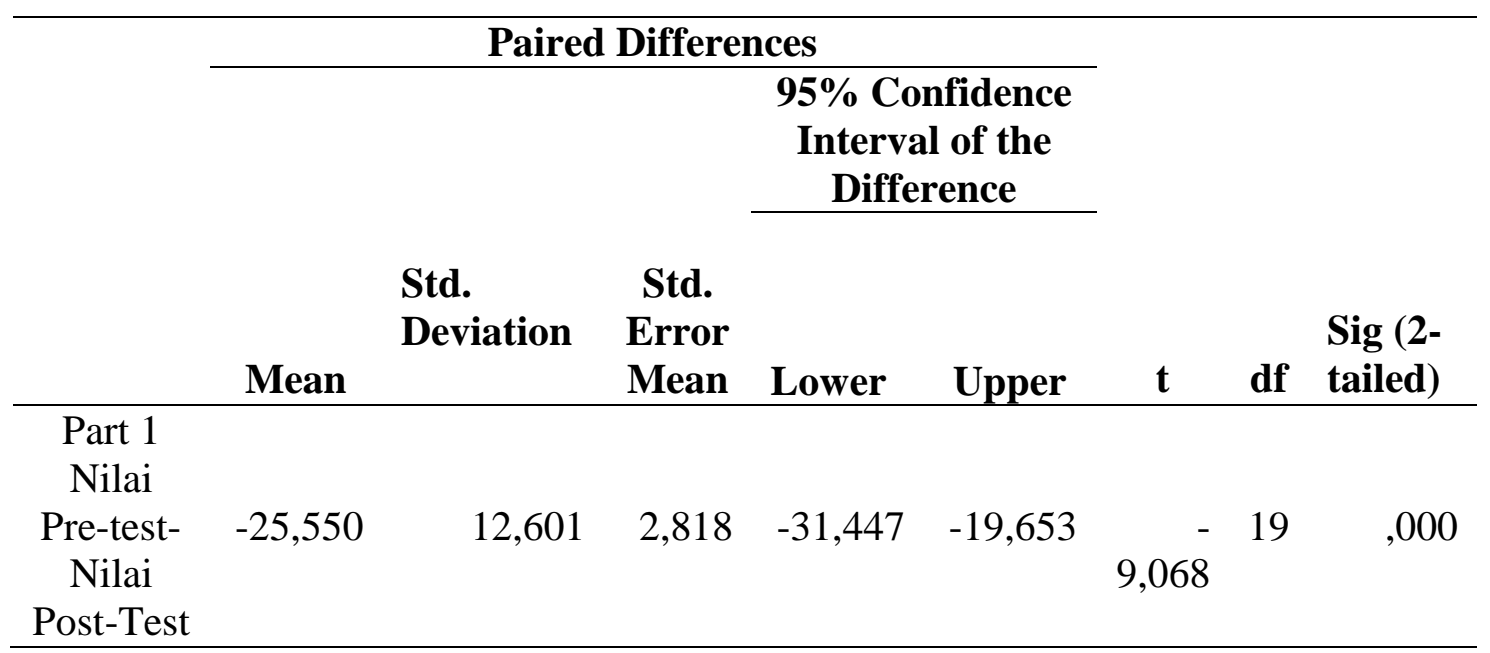

Based on the result of the test, through a T-Test using SPSS 22, researchers analyze the data, and the result is the t-count was 9,068. After comparing the 5\% significance level and the degree freedom (pdf) of 19 and the $t$ count $(9,068)$, which was higher than t-table (2.086). There is a significant difference between the score in some aspects in speaking skill shows the use of the PST supports the students to speak.

\section{DISCUSSION}

The use of Picture Strip Story in students' speaking ability gives effectiveness. It proved through some of the research findings of Novianda (2017), Damayanti, (2017), Prawerti, (2015). Through applying the Picture Strip Story can improve the students' speaking ability. Stimulate students to express their idea through the PST. In this research find the data that shows the Picture Strip Story gives a positive effect on students speaking skills, especially in students speaking skills. Through some tests, the researchers find that there is a significant difference in students' scores before conducted the treatment using the Picture Strip Story. The researchers find there are 16 students who got the 31-60 scores (80\%), three students who got 61-90 scores (15\%), and one student who got $10-30$ scores $(5 \%)$. The percentage of the test shows that there are five aspects 
that support the students' speaking skills. They are Fluency. 1. The percentage of students' fluency in the pre-test is $17,5 \%$ and in the post-test $23 \%$. 2. The percentage of students' vocabulary in the pre-test is $20,2 \%$ and in the post-test is $25,3 \%$. In grammar, the percentage in the pre-test is $22,1 \%$, and in the post-test is $25,5 \%$. In pre-test, pronunciation is on $15,6 \%$ and in the post-test $20,5 \%$. In the pre-test, comprehension is on $19,8 \%$, and in the post-test is $23,1 \%$.

It means that the students are on a low level in speaking, according to table 3.1. Therefore, The researchers conduct the treatment to find whether the differentiate of using Picture Strip Story in teaching speaking or not. After giving the treatment for three meetings, researchers also conduct the post-test, to find whether there are differences after teaching speaking using the Picture Strip story and before taught speaking using the Picture Strip Story. In post-test, the researchers found that there are some students who got high scores after taught speaking using the picture strip story. There are 19 students who got the 61-90 scores $(95 \%)$ and one student who got 31-60 scores (5\%). It means that the students' speaking skill increase. Through the scores between Pre-test and Posttest, shows the significant after being taught using the PST. The same result of the research findings above also finds in this research where the students' speaking ability was improved. It proved using the different scores of the pre-test mean scores $(48,00)$ with the post-test mean score $(73.55)$ that was higher than the pretest mean score $(48,00<73,55)$. It was also supported by the t-test, where the $t-$ count of 9,068 that bigger than the t-table of 2,068. It was showed that H0 was rejected while $\mathrm{H} 0$ was rejected. The significance value was 0,00 was lower than the significance level; it was 0,05 . Researchers conclude that there is a positive effect on students' speaking skill through students' speaking scores test after being taught by the picture strip story at the second grade of SMP Yayasan Pangeran Antasari.

\section{CONCLUSION}

Based on the data analysis, there was any effect of the students' scores before and after being taught by using the picture strip story From the test; the Ha was accepted while Ho was rejected. Through the scores between Pre-test and Post-test shows a significant difference after being taught using the PST. It was concluded that Picture Strip Story gives a positive effect on students' speaking skills, which could be seen through the difference in the pre-test mean score that made a lower result than in the post-test mean score. 


\section{REFERENCES}

Izumi, I., C. (2017). The Study Between Students' Anxiety and Speaking Ability at the First Grade Students of SMA Negeri 1 Kabupaten Tangerang.A Script. The University Of Lampung.

Damayanti, S., E. (2017). The Used of Picture Strip Story to Improve Students Speaking Skills. The State Islamic Institute of Surakarta.

Kosdian. O. (2016). Improving Students' Speaking Skills by Using Picture Strip Story. Indonesian EFL Journal, 2(2), 100-109.

Khairunnisa.(2015) The Effect of Using Pictures Strip Story Technique Toward Speaking Ability of The Second Grade Students at MA AL-IHSAN, BuluhRampai. State Islamic University of Sultan Syarif Kasim Riau, Pekanbaru.

Leong, L., M, Ahmadi S., M. (2017). An Analysis of factors Influencing Learners'English Speaking Skills. School of Educational Studies, Universiti Sains Malaysia.

Novianda, R. (2017). Teaching Speaking by Using Picture Strip Story. Syiah Kuala University. Banda Aceh.

Purba. D., Marbun, W. (2019). The Implementation of Picture Strip Story in Improving Students' Speaking ability of DarmaAgung University.

Tarigan H. G. (1990). Prinsip-Prinsip Dasar Metode Riset Pengajaran dan Pembelajaran Bahasa. Bandung: Angkas.

Toyib, R. Syafi'I, A. (2018). Role-Play as a Method to Overcome Students' Anxiety in Speaking Skill. STKIPAl-Hikmah Surabaya.

Prawerti, C., R. (2015). The Effectiveness of using Strip Story Technique in Teaching Speaking Towards Students' Speaking Achievements. Institute Agama Islam NegeriTulungagung.

Rifa'at, A. A. (2018). Stimulating You to Speak; A Strip Story As A Technique In Teaching Speaking. Sitikhadijah, Palembang. 